\title{
CHANGING DISTRICT BORDERS IN THREE NORTH-EAST HUNGARIAN COUNTIES (1773-1910)
}

DOI: http://dx.doi.org/10.18509/GBP.2016.33

UDC: $341.218 .4(439-18)$, ,1773/1910“

\author{
Dr. Róbert Bagdi \\ College of Szolnok, Hungary
}

\begin{abstract}
The County system of Hungary dates back to the first millennium, and Hungarian nobility insisted on it over centuries; whenever the rationalization of the system was attempted by Vienna, these efforts lasted only for a short time. Every county had several districts to make administration easier, and leaders of the given county were allowed to delimit the borders of these districts. It seems that the more stable the borders of the Counties were, the more unstable the borders of the districts happened to be.

Our examined area consists of Zemplén, Ung, and Bereg Counties with around 900 settlements. We attempted to reconstruct the borders of the districts in 1773, in the early 19th century, in 1880 and 1910. We used four different sources, e.g. registers of settlements, or censuses, all of them issued in the 19th century or around the World War I, in order to create maps about these districts. These administrative units changed many times during the examined period. It seems, natural features, e.g. rivers, or mountains were the main determinative factors of these borders. The first examined year, 1773, represents the (unreasonable) persistence of a late mediaeval system, and 1910 shows the more complex system, in which the decision-makers tried to work out a 'centre-attraction zone' scheme.
\end{abstract}

Keywords: North-East Hungary, districts, registers of settlements, censuses

\section{INTRODUCTION}

The County system of Hungary is dated back to the first millennium, and Hungarian nobility insisted on it over centuries; although the rationalization of the system was attempted by Vienna, these lasted only for a short time. The counties were the most important elements of the public administration (medium level). Every county had several districts as the lower-medium level of the public administration, to make administration easier and collecting taxes easily. The districts became important territorial units in the Dualistic Era, the first Law voted about it in 1870 (Law of Municipals). The districts did not have local governments, but they had a principal to rule the settlements. Borders of these districts were designated by the leaders of the given county.[1] We have sources from the $18^{\text {th }}$ century about these classifications in settlement registers. All these documents were issued: by the state or in some rarely cases by the Churches. We have several source types from the $19^{\text {th }}$ century, made by official state institutions, e. g. the Hungarian Central Statistical Office which executed a census once in every decade in Dualism Era and published the results. Hungary had 672 districts in 1873.[2] Also some researchers collected data about the Hungarian settlements and the results were published on County and district-scale. All documents preserved a different classification of districts during the 'the long $19^{\text {th }}$ century' and our aim is to present these frequent modifications from four periods based on original sources. The former Zemplén, Bereg 
and Ung Counties from historical North-Hungary are proper selections to the show the variety of changing classifications, because plains and mountains (natural borders) also characterized the physical environment.

Zemplén, Ung and Bereg Counties expanded from the northern border of the Hungarian Kingdom to the south, to the River Tisza. Borders of the Counties were determined mainly by the physical environment, e. g. the watershed of Carpathian Mountains (600$1200 \mathrm{~m}$ ) separated the counties from the Polish (later Austrian) territories to the north. Zemplén County was bordered by the Eperjes-Tokaj Mts. (600-1100 m) westwards. The boundary between Zemplén and Ung was partly dominated by the Vihorlát (1074 m), the only mountain chain that hindered the North-South connections, turning them into EastWest direction. The fluvial system was centripetal, rivers from north flow towards River Tisza to the south with the exception of the streams of Ung County flowing towards Zemplén County to the west. The direction of the main routes clearly matched the direction of water flows. The three Counties cannot be regarded as a homogeneous landscape since they included a series of transitional and contact zones from high mountains with sometimes large, in other cases characteristically small but isolated settlements in the north, through sparsely populated hilly regions with many but small settlements, to densely populated plains in the south with larger settlements.

\section{SOURCES AND METHODS}

Our first examined source originated from 1773 entitled Lexicon locorum regni Hungarae populosorum anno 1773 officiose confectum, but was published only in 1920.[3] This document is a Register of Settlements, which contains the most important data about the population of the given settlement. The document gives information about 8742 settlements of the Hungarian Kingdom, arranged primarily by Counties, second by districts in alphabetic order. Names of the settlements were published and ranked in Latin language, but Hungarian and - if existed - other name variants can also be found in this document (e.g. German, Slovakian, Romanian, Ukrainian, Serbian or Croatian). Some information can be found about the legal status, so the Latin word 'oppidum' means 'town', while the note 'pagus' equal with 'village'. The most important denomination of the settlements is also given in Latin (Catholicae, Craeci ritus, Augustanae, Helveticae, Acatholici, Schismaticae) such as the spoken language - with some generalizations regarding Slavic dialects (i.e. Slavonica).

Elek, Fényes worked as a statistician, who spent more than 10 years during the 1820's and 1830's with visiting the villages in the countryside to collect data about the local population from birth and martial registers. He also grouped the collected data in his work first by counties in alphabetic order, second by districts. Ha assessed the number of population, the most common spoken languages, the dominant denominations for each settlement, and a short description about the local life of the residents. He published the results between 1836 and 1840 in six volumes with more than 4.000 pages. However, the level of his work remained uneven, some Counties did not provide enough or reliable data, sometimes older data (1790s or 1828 from Ludovicus Nagy were repeated instead of refreshing them. The data of the three investigated counties can be found in the $3^{\text {rd }}$ volume.[4]

The source of the third classification is the second organized census of the Dual Monarchy from 1880, which was also published, containing information about settlements in districts order. The importance of this census is that data were published at settlements- 
scale in contrast the previous one (1869), which published the results at only districtlevel, thus it was impossible to reconstruct the exact borders of the original districts. We know only the names of these districts (from 1869), and all data added up in every district and only the last results are published. The census of 1880 contains data about the mothertongue as well (beyond religion, literacy, etc.).[5]

The names of the settlements did not change until the last decade of the $19^{\text {th }}$ century. According of the Law IV/1898 the names of the settlements had to receive an official registration certificate. Every settlement was assigned an official (mostly new) name, which marks them off from other ones, and these registered names were compulsory to use. All counties except four received new, registered (and often 'Magyarized') settlement-names between 1900 and 1912. The former Hungarian Kingdom had around 12 thousand settlements, and more than the half of them got new names (with new orthographies, new attribute nouns, new translated forms or sometimes new given 'Magyarized' names, etc.). Zemplén, Ung and Bereg Counties had new settlement names in 1904, so the published results of the last census from 1910 contains the new names. [6] The division of the settlements among districts was also modified a bit between 1880 and 1910; new districts were established, or villages were replaced from one to another.

To show the four different classifications of the districts in the examined three counties on maps we needed to identify every village before and after the official registration certificate in the investigated documents (see Ulič/Ulics in Zemlén County which was called Utcás after 1904 by translating the Slavic-Rutnenian name to Hungarian). However, districts were also modified so we need to identify all of the 900 settlements one-by-one, to determine in which districts we can find them.

Reconstructing the former divisions is not a popular theme in Hungary. Only János Barta tried to identify every settlement in Zemplén County in the year of 1787, this classification ordered by Joseph II, but it was Robert Bagdi who compiled the maps in his published book in 2009.[7] Other researchers examined mainly the economic characters of districts.[8]

\section{DISTRICTS IN NORTH-EAST HUNGARY BETWEEN 1773 AND 1910}

An 'archaic' form in the district-system persisted and survived in every examined County at the end of the $18^{\text {th }}$ century. Zemplén had only 4 (Hegyalja, Bodrogköz, and district of Varannó and Nagymihály), Ung only 3, while Bereg also only 4 districts. See Map 1 The southern parts of these Counties were a bit more densely inhabited area mostly with inhabitants of Hungarian mother tongue. The northern part of these Counties was mostly mountainous with sparsely populated Slavic speaking villages among mountains. Borders of the districts were determined by rivers and streams in Zemplén, for example Bodrogköz is a territory which consisted of all the settlements extending between the Tisza River and Bodrog River. Hegyalja is also a natural unit, dominated by wine-yards on the southern slopes of the present day Zemplén Mountain (before World War I it was called Eperjes-Tokaj Mountain). The Ondava River formed the border between Varannó and Nagymihály district, which seemed to be the most stable border in Zemplén County. None of the modifying of district-borders referred to the Valley of Ondava River before World War I. 


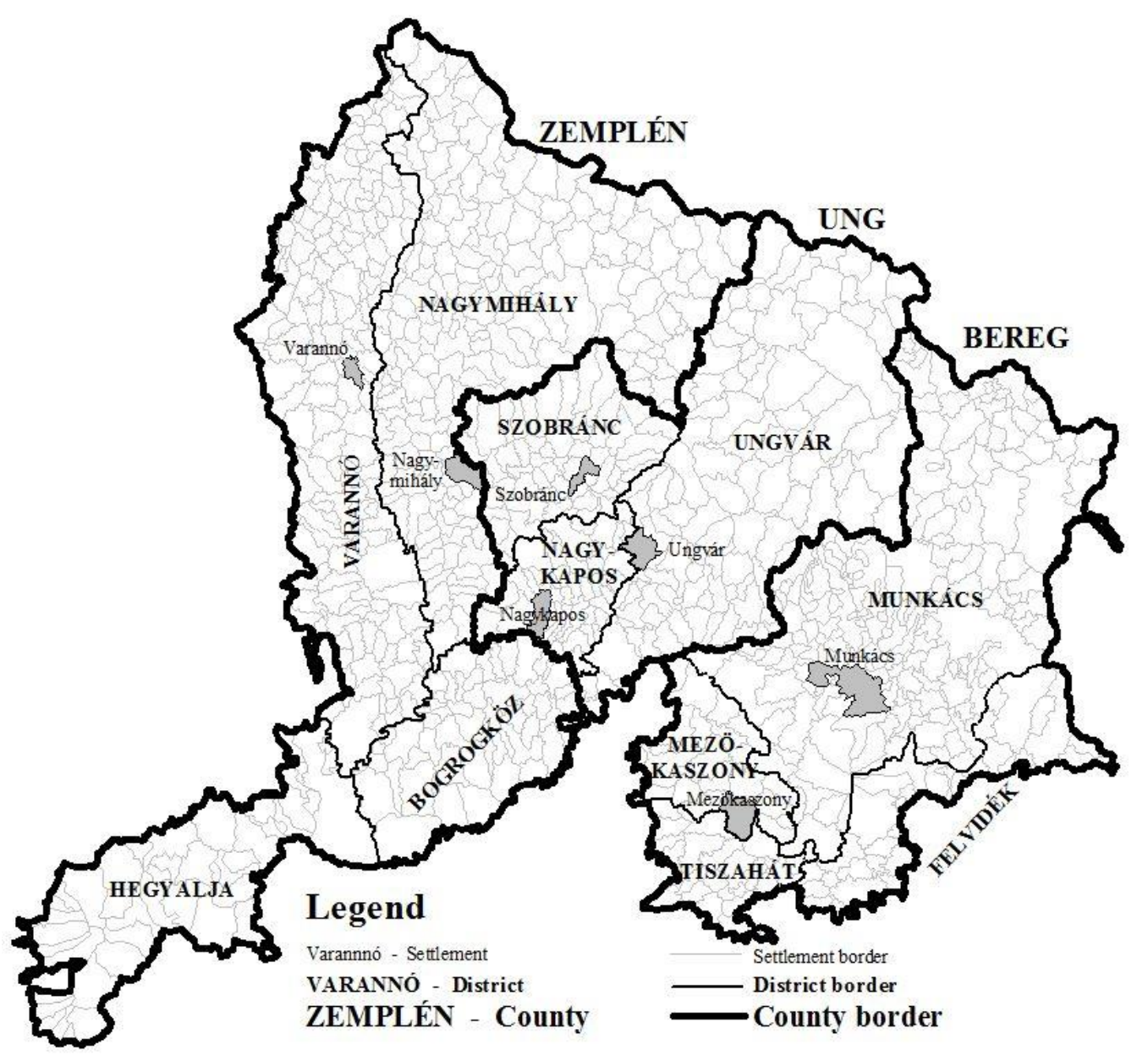

Map 1. Districts in North-East Hungary in 1773

Source: Own edition, data based on Lexicon Locorum [3]

Ung County had only 3 districts, it seems that the western part of the county was the most important territory, because the smaller two districts, Szobránc and Nagykapos could be found here (higher density of population). The centre of the county, Ungvár was the key settlement in the county; two third of its territory belonged to it. This county did not have as clear natural district-borders as Zemplén County. The territory of the Szobránc district was composed of the southern slopes of the Vihorlát Mountain, and the lowlands between the Ung and Laborc Streams, the Greek Catholic church was the most popular denomination here. Bereg County had only four districts, the central and the northern parts composed the Munkács district. The eastern parts of the county belonged to Felvidék ('Uplands') district, all the villages along the Borzsa and Borzsava Stream belonged to this district. Most of the villages along the River Tisza belonged to Tiszahát (the word means 'the Back of Tisza River') district. Mezőkaszony district was also a small one; dominantly Hungarian speaking settlements were incorporated into this territorial unit. See Map 1

Examining all districts, it seems that only the densely populated southern parts of the counties were classified into different districts. The northern parts of the examined counties were connected with the central parts. The main reason could be that the mentioned districts functioned as territorial units of collecting taxes. It seems without a doubt that not a high amount of taxes was collected from the northern parts (lower density 
of population), thus there was not demand for other districts along the Hungarian-Austrian border.



Map 2. Districts in North-East Hungary at the first half of $19^{\text {th }}$ century

Source: Own edition, data based on Fényes, Elek [4]

There were some changes in the districts' classification system during the early $19^{\text {th }}$ century. Elek, Fényes enumerated a few new districts. See Map 2 Two districts in Zemplén were divided into two parts; the southern part of the previous Varannó district became Újhely district; while the northern part named after Sztropkó town, whereas the name of Varannó disappeared. The huge Nagymihály district was also divided into two parts, Göröginye and Homonna. The Homonna district was organized along the Ciróka Stream, and the Laborc River. The Göröginye district was organised from the former north-western part of the previous Nagymihály district along the Olyka Stream. The Szerednye district was formed in Ung County from the villages of the mountainous southeast parts, and all the banks of the River Tisza belonged to it. In Ung and Bereg County, the two county seats lost the central territories, and only the northern parts remained within their districts. The Felvidék district (Bereg County) also was enlarged by villages from the central territories. Mezőkaszony district was moved to the northern direction, it lost the banks of the River Tisza, but some villages from the northern mountainous territories were annexed to it. See Map 2 


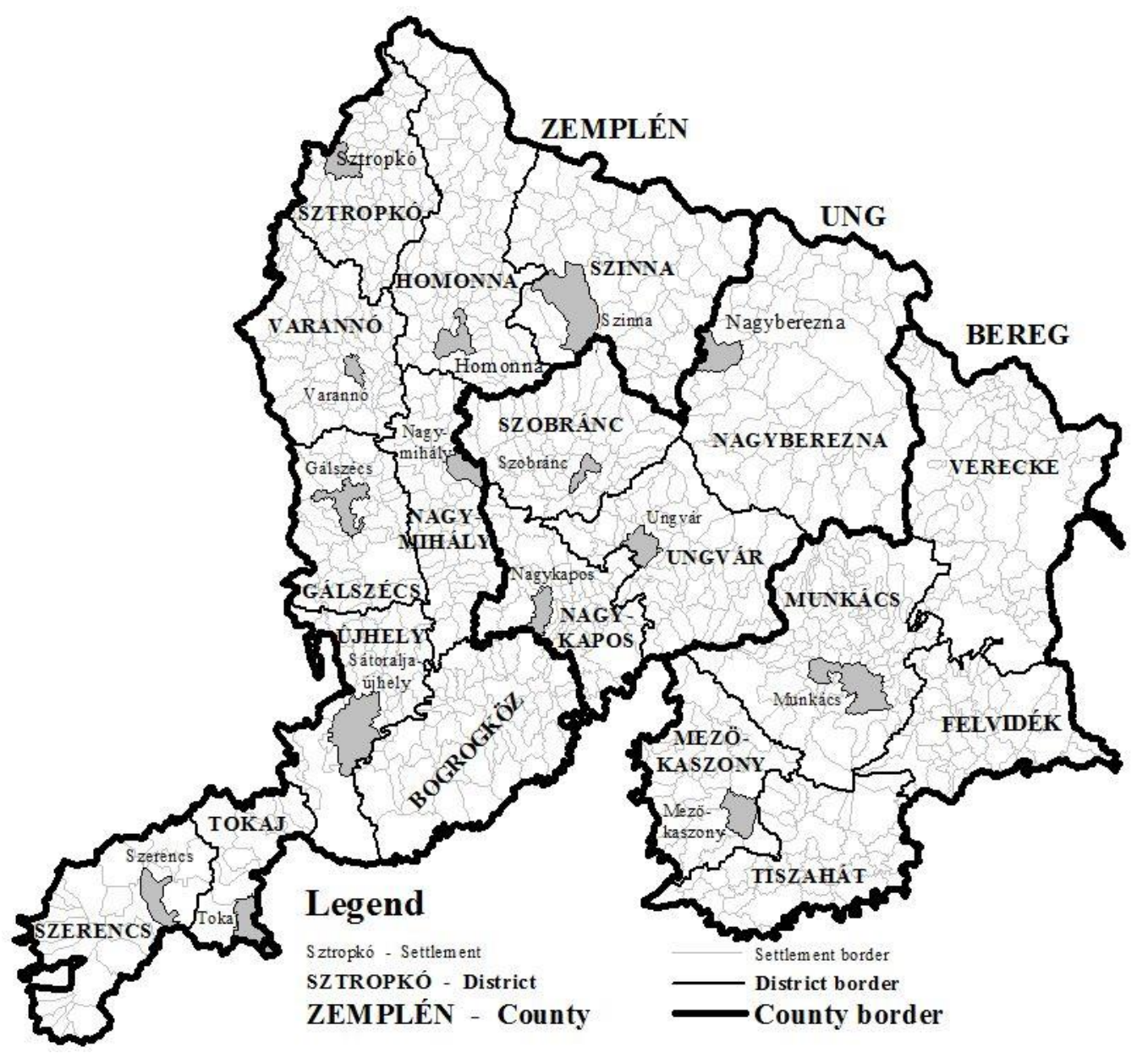

Map 3. Districts in North-East Hungary in 1880

Source: Own edition, data based on census of 1880 [5

The modernization of the Hungarian state had a new impulse after establishing the Dual Monarchy of Austria and Hungary in 1867. Many new districts appeared by 1880. See Map 3 Only Bodrogköz was the only district, which remained the same unit as in the previous examined periods. Hegyalja was divided into Szerencs and Tokaj districts; Újhely was divided into Újhely and Gálszécs districts, while Sztropkó was divided into Varannó and Sztropkó districts. The name of Nagymihály appeared again among districts and the eastern part of Middle-Zemplén belonged to it. A new administration unit was established at the eastern part of the Homonna district, and named after Szinna village, which had the highest population number (2197) in this area. Only one district, Nagyberezna was organized in Ung County by 1880 with all the northern territories. Szerednye district was divided between Nagykapos and Munkács district. See Map 3 A new district was organized at the northern part of Bereg County with the name of Verecke (a mountain pass in the Carpathians). The mountainous parts of Mezökaszony were annexed to Munkács. The bank of the River Tisza was divided between Mezőkaszony and Tiszahát district. See Map 3 


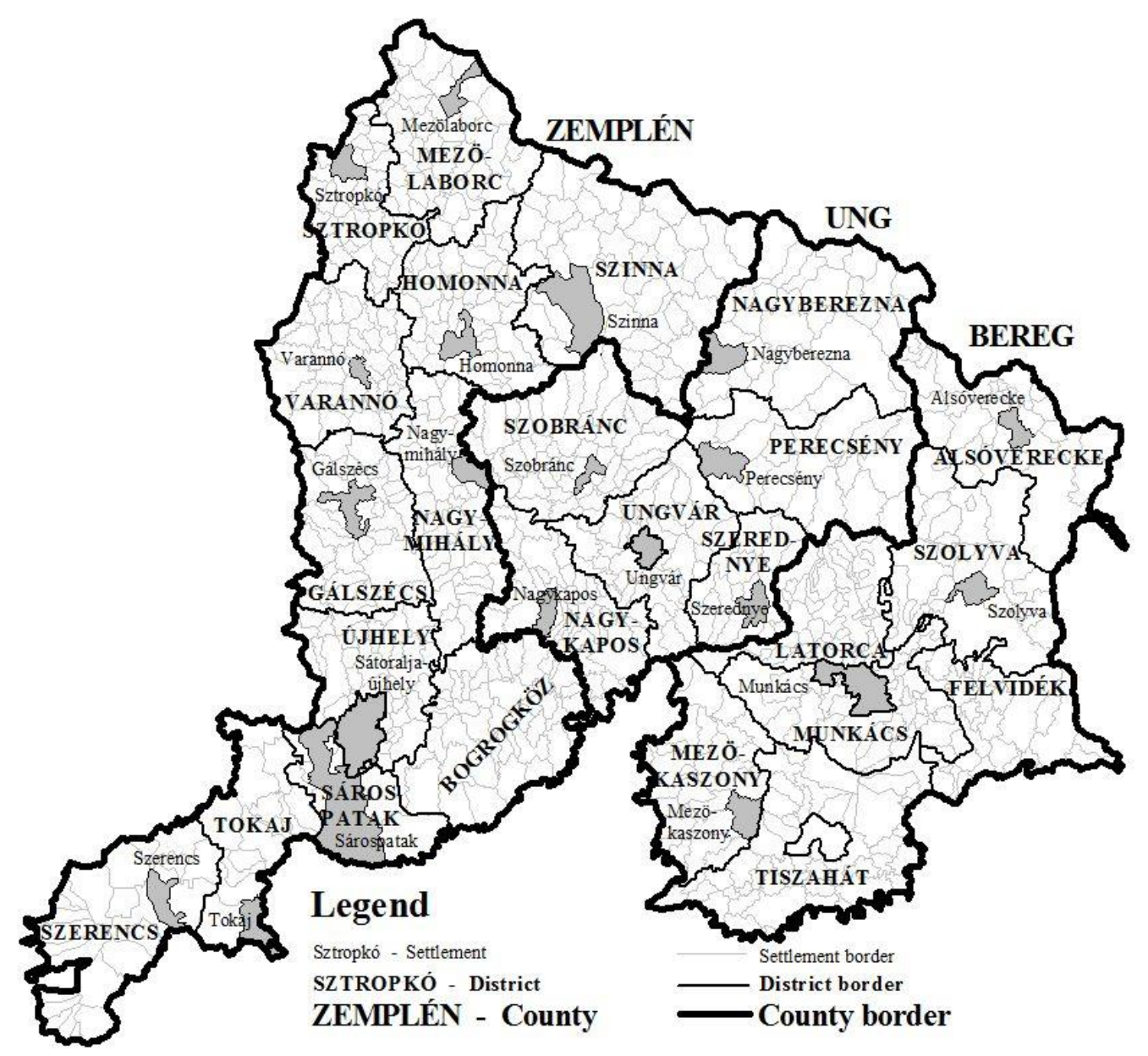

Map 4. Districts in North-East Hungary in 1910

Source: Own edition, data based on census of 1910 [6]

Few changes occurred by 1910 in the three examined Counties. The Sárospatak district was formed from south-west parts of Újhely district, but only 9 settlements belonged to it. Homonna lost its northern parts and thus the Mezőlaborc district was organized with 49 settlements. In Ung and Bereg County the two northern districts was cut in half and Perecsény (Ung) and Szolyva (Bereg) districts were organized. Two new administrative units were established on the mountainous territory between Ungvár and Munkács, Szerednye (Ung) and Latorca (Bereg). The name of Latorca referred to a river.

\section{SUMMARY}

We illustrated the changes in the administration system in North-East Hungary for four different periods. The first one was equal with a 'medieval' system having only a few districts. The second one shows that decision makers tried to find a better classification. The weak point of this classification is that, in many cases, the most important settlements laid along the district-borders. Many new districts were organized by 1880 , because the counties tried to work out an efficient system. During the next three decades only small corrections were made, with establishing new districts at the mountainous area. The system of districts in 1910 shows the most complex system, in which the decision-makers tried to work out a 'centre-attraction zone' scheme. Around 40-50 settlements could be found in each district, each one had a 'centre', which had at least a bit higher population 
number. Physical environment also played an important role to determine the borders of these districts during the $19^{\text {th }}$ century up to 1910 .

\section{REFERENCES}

[1] Barta, Attila. A magyar államigazgatás alsó-középszintjének átalakítása 2012-ben: A járások feladataira és szervezetére vonatkozó főbb megállapítások, Kodifikáció és közigazgatás, Hungary, vol. 2, pp 28-38, 2012.

[2] Hajdú, Zoltán. A közigazgatási térfelosztás változásai Magyarországon. (Changes in the Administrative Spatial Division of Hungary.) Tér és Társadalom, Hungary, vol. 1, pp. 5-21, 1996.

[3] Magyarország helységeinek 1773-ban készült hivatalos összeírása. (Lexicon locorum regni Hungarae populosorum anno 1773 officiose confectum.) Budapest, Hungary, pp $385,1920$.

[4] Fényes, Elek. Magyarországnak 's a' hozzákapcsolt tartományoknak mostani állapotja statisztikai és geographiai tekintetben, Pest, Hungary, vol. 3, pp 455, 1838.

[5] A Magyar Korona Országaiban az 1881. év elején végrehajtott népszámlálás főbb eredményei megyék és községek szerint részletezve, Budapest, Hungary, pp 415, 1882.

[6] A Magyar Szent Korona Országainak 1910. évi népszámlálása, vol. 42, Budapest, Hungary, pp 880, 1912.

[7] Barta, János. „Ha Zemplin vármegyét az útas visgálja”, Debrecen, Hungary, pp 407, 2009.

[8] Demeter, Gábor \& Radics, Zsolt. A gazdasági fejlettség regionális különbségeinek vizsgálata az Osztrák-Magyar Monarchia utódállamaiban járásszintü adatok alapján. Történeti Földrajzi Közlemények, Hungary, vol. 6, pp 233-246, 2015. 